\title{
Air-Conditioning and the Transmission of COVID-19 in Indoor Environment
}

\author{
Tosin T. Oye \\ School of Engineering and Built Environment, Edinburgh Napier University, UK
}

Naren Gupta

School of Engineering and Built Environment, Edinburgh Napier University, UK

Keng Goh

School of Engineering and Built Environment, Edinburgh Napier University, UK

Toyosi K. Oye

School of Engineering and Built Environment, Edinburgh Napier University, UK

Received: March 29, 2021 Accepted: May 12, $2021 \quad$ Published: May 23, 2021

doi:10.5296/emsd.v10i3.18461ＵRL: https://doi.org/10.5296/emsd.v10i3.18461

\begin{abstract}
Substandard ventilation in restricted air-conditioning indoor places is allied with upsurge in the respiratory infections' transmission. There have been several COVID-19 spread occurrences connected with indoor environment, together with a few from pre-symptomatic situations. Ventilation role in averting coronavirus transmission is not precise (i.e., through inhibiting transmission of an infectious dose to susceptible individuals or preventing the spreading of contagious particles to lessen the risk of transmission). SARS-CoV-2 is believed to be mainly spread through significant respiratory droplets, nevertheless, a growing amount of epidemic information associate aerosol role in the epidemics of coronavirus. Aerosols comprise of droplet nuclei and little droplets which stay in the air for longer than significant droplets. Recent studies show that coronavirus particles can stay transmissible on numerous substances, including aerosols within the indoor environments, as well as the contagion period contingent on humidity and temperature. Thus far, COVID-19 transmission via air-conditioning systems is unclear, but it is considered possible.
\end{abstract}


Keywords: COVID-19, Air-conditioning, Indoor environment, Ventilation, Transmission, Epidemic, Human health

\section{Introduction}

Numerous epidemic exploration accounts have revealed that transmission of SARS-CoV-2 can be predominantly active in confined, congested indoor environments such as offices, factories and in the course of indoor occurrences - e.g., cruise ships, dance classes, worker dormitories, shopping centres, parties, restaurants, churches and gatherings at ski resorts (Leclerc et al. 2020). Study by Hamner et al. (2020), unfold that there are demonstrations which transference can be related to exact events, such as singing in a choir or in the course of religious services that may be categorized through increased respiratory droplets production via singing and loud speech. In China, an investigation of 318 occurrences transmitted in the entirely incidences except one happened in indoor places (Qian et al. 2020). Nevertheless, outdoor gatherings have likewise been implicated in COVID-19 transmission, characteristically those related with masses, such as football matches (Azzoni and Dampf, 2020) and carnival festivities (Deutsche, 2020), emphasizing the danger of gathering still at outdoor functions. Albeit subjection in air-conditioning indoor environments is likewise very common in the course of such occasions.

Consequently, there is continuing dispute about the degree to which the transmission of aerosol triggers contamination. Nevertheless, it has been largely acknowledged that it does take place, particularly in enclosed environments. There is a likelihood that air-conditioning might be a possible transmission route - sucking in particles of the coronavirus which is breathed out through a contaminated human and subsequently carrying those contagious fragments back out in the same indoor space or even another indoor environment. Basically, additional transmissible infections such as SARS, smallpox, influenza, chickenpox, tuberculosis and measles have completely been demonstrated to circulate via air-conditioning systems (Oye et al. 2020b). Although obtaining definitive conclusions concerning the role that air-conditioning procedures may possibly play in transmitting SARS-CoV-2 is difficult. Similarly, there are only a small number of published studies examining the matter, and specialists acknowledge there has limited investigation into the part of air-conditioning in transmission of the novel coronavirus.

Air-conditioning systems bring in outside air and transmit out an equivalent indoor air quantity as needed through the procedure of the building. The exchange of air is expected to weaken and eliminate pollutants such as chemical emissions and particles from building substances and discharges from humans that produce odors (Oye et al. 2020b). Several schemes retransmit indoor air, which may possibly in theory transmit virus-related aerosol fragments from one indoor environment to another, although it is unclear to date that this has triggered SARS-CoV-2 contaminations. Numerous systems retransmit indoor air which assists to eliminate unwanted particles from the indoor air when it passes across the filters prior to being reverted to the conditioned environments. However, studies suggests that outdoor warm weather triggers individuals to pursue indoor air-conditioning comfort. In indoor environment, there is less air circulation and more prospect to transmit infection. 


\section{Indoor Environment Case Study}

Research study by Oye et al. (2020b) reveal that the use of air-conditioning has mostly been used due to life-threatening summer conditions. Thus, there are almost certainly air-conditioning systems within indoor environment from workplaces to every single room in the building. With so much connection to air-conditioning, there has been a persistent dispute as to whether the air-conditioning has an unfavorable impact on the human body and foster the transmission of COVID-19 within the indoor environment. Nonetheless, research likewise uncovered that human wellbeing is deemed as the major concern due to the transmission of coronavirus. According to recent study by Oye et al. (2020b), residents in building with frequent utilization of air-conditioning have greater rates of illness than people in buildings with natural air-circulation. Investigations demonstrate that persons who work in a setting that is over-air-conditioned can experience continuous fatigue and chronic headaches. Similarly, people who work or live-in buildings which are consistently being pumped full of cool air can equally suffer incessant mucous membrane irritation and breathing difficulties. This puts people more vulnerable to catching the colds, flu, coronavirus, and other diseases connected with the use of air-conditioning (Oye et al. 2020b).

Therefore, the extent of period that individuals reside within the indoor environment seems to be connected with the level of coronavirus attack. For instance, in Washington, US, in a 2.5-hour choir rehearsal, there were thirty-two confirmed and twenty possible secondary coronavirus occurrences amid sixty-one participants (85.2\%). At a call centre in South Korea, there was an outbreak rate of $43.5 \%$ amid two hundred and sixteen workers on the 9 th floor of the call centre in an epidemiological examination, demonstrating widespread transmission in a full indoor workplace setting (Park et al. 2020). Consequently, almost every one of the affected people on the ninth floor were sitting on the sideways which are similar. There was no noticeable association amid transmission risk and the interval from the key situation on this lateral of the ninth floor. Park et al. (2020) likewise finalized that the time span individuals was in connection played the utmost significant part in SARS-CoV-2 transmission, because the occurrences were restricted virtually and completely to the 9th floor, in spite of communication with co-workers in other locations (such as in lobby and elevators).

\section{Indoor Ventilation}

Ventilation is the means of supplying outside air to a building or space through mechanical or natural route (ISO, 2017). It regulates how swiftly room air is eliminated and substituted over time. For instance, it is essential to eliminate greenhouse gasses from outdoor air prior to getting into a building, through employing suitable filtration systems. Research studies by Thatiparti et al. $(2016,2017)$ reveal that ventilation performs a significant part in eliminating exhaled virus-laden air, therefore reducing the total intensity and thus any successive amount breathe-in by the inhabitants. Suitable ventilation distribution systematically guarantees that sufficient reduction is accomplished when required while preventing the accumulation of disease-causing pollution. Therefore, the main notion is to supplant polluted air with clean air, although from time-to-time district impediments to this procedure may possibly happen, e.g., where blinds are drawn, or partitions are employed for confidentiality or therapeutic 
processes. Supplementary procedures may be required if these impediments are applied to attain necessary efficiency of ventilation.

According to Phiri (2014), suitable ventilation procedures are previously in place in several hospice locales, for emergency and routine processes to safeguard against contact and droplet transmission. Appropriate ventilation likewise shields the inhabitants against the level of indoor $\mathrm{CO}_{2}$ and airborne spread. The scope to improve the rates of ventilation when required may vary and may be to some extent restricted via their innovative design conditions and execution. Also, numerous clinics are naturally ventilated, nevertheless, if the flow of air is impeded (for instance, shutting doors and windows), airborne pathogen and indoor $\mathrm{CO}_{2}$ concentration can quickly increase heading to an intensified risk of airborne transmission and illness (Gilkeson et al. 2013). The concepts of natural ventilation relate to healthcare services in both established and developing nations in satisfactory climatic environments. The plan, process and upkeep of naturally ventilated services is not simple, and inclusive support is accessible (WHO, 2009).

Research studies by Oye et al. (2020b; 2020d) proposes that strategies of air-conditioning control can typically be altered through smart computational control techniques to improve ventilation to a specified amount in the inhabited places. Similar process can likewise be employed to eliminate or decrease the dangers of airborne transmission between inhabitants. Nevertheless, this is not through a straightforward method, as air-conditioning systems are complicated and typically designed for specific buildings in basic functioning limits. Several conditions require to be measured separately from the rate of ventilation, as well as temperature control, relative humidity, and indoor $\mathrm{CO}_{2}$ control (Oye et al. 2020d). Such systems can be exclusively modified as required via air-conditioning engineers, e.g., to decrease the risks of airborne transmission, improve the temperature control and reduce the level of indoor $\mathrm{CO}_{2}$ in indoor environment.

\subsection{COVID-19 and the Air-Conditioning}

The state-of-the-art studies have revealed that it is not reasonable to elucidate the role of direct interaction and physical proximity, and the feasibility of secondary spread via contaminated objects or surfaces, or the distance of lengthier transmission by aerosols. Also, there is a possibility for prejudice in publication, with smaller number of transmissions in adverse discoveries; and validation prejudice, with research that are published re-substantiating well-known knowledge. Albeit up-to-date evidence form establishes transmission risk in full indoor locations and the significance of merging necessary prevention measures bundles.

Numerous recent investigations have addressed ventilation role in the outbreaks of COVID-19. Three occurrences elaborate a key circumstance that was accounted to be pre-symptomatic, and enclosed space air-circulation, assisted by means of air-conditioning. Furthermore, there were ten occurrences amongst three families, in an eatery outbreak in Guangzhou, China (Li et al. 2020). Symptoms were developed, between 26 January and 10 February 2020, having dine at the same eatery, which is a five-floor structure lacking windows, on 23 January. Also, more than a meter apart were their tables. That evening, the 
key incident was pre-symptomatic, developing a cough and fever. The minor incidents were sitting along the flow of air produced via the air-conditioning system, whereas patrons sitting in another place in the eatery were not affected. Studies ascribe spread to the respiratory droplets' transmission carrying COVID-19 by way of the flow of air produced via the air-conditioning.

\subsection{Results}

Statistics regarding the research strategy, the nation of study, and the study environment, including the investigation's result, were obtained. The research outcome held in the current assessment were qualitatively synthesized. Therefore, Table 1 presented the results of COVID-19 epidemics in air-conditioning indoor environment.

Table 1. COVID-19 epidemics in air-conditioning indoor environment

\begin{tabular}{|c|c|c|c|c|c|c|c|}
\hline $\begin{array}{l}\text { Authors } \\
\text { and Year }\end{array}$ & Publication & Virus & Country & Study Type & Incident & Environment & $\begin{array}{l}\text { Air-Conditioning } \\
\text { system }\end{array}$ \\
\hline $\begin{array}{l}\text { Li et al., } \\
(2020)\end{array}$ & Pre-print & $\begin{array}{l}\text { COVID- } \\
19\end{array}$ & China & $\begin{array}{l}\text { Observational } \\
\text { with } \\
\text { experimental } \\
\text { modelling }\end{array}$ & 10 & Restaurant & $\begin{array}{l}\text { Supported by } \\
\text { computer } \\
\text { simulation }\end{array}$ \\
\hline $\begin{array}{l}\text { Lu et al., } \\
(2020)\end{array}$ & $\begin{array}{l}\text { Peer review } \\
\text { journal }\end{array}$ & $\begin{array}{l}\text { COVID- } \\
19\end{array}$ & China & Observational & 10 & Restaurant & Suspected \\
\hline $\begin{array}{l}\text { Mizumoto } \\
\text { and } \\
\text { Chowel, } \\
(2020)\end{array}$ & $\begin{array}{l}\text { Peer review } \\
\text { journal }\end{array}$ & & Japan & Observational & 355 & Ship & $\begin{array}{l}\text { Not endorsed with } \\
\text { the spatiotemporal } \\
\text { dissemination of } \\
\text { incidents }\end{array}$ \\
\hline $\begin{array}{l}\text { Xu et al., } \\
(2020)\end{array}$ & Pre-print & $\begin{array}{l}\text { COVID- } \\
19\end{array}$ & Japan & Observational & 355 & Ship & $\begin{array}{l}\text { Not endorsed with } \\
\text { the spatiotemporal } \\
\text { dissemination of } \\
\text { incidents }\end{array}$ \\
\hline $\begin{array}{l}\text { Zhang et } \\
\text { al., (2020) }\end{array}$ & $\begin{array}{l}\text { Peer review } \\
\text { journal }\end{array}$ & $\begin{array}{l}\text { COVID- } \\
19\end{array}$ & Japan & Observational & 355 & Ship & Suspected \\
\hline $\begin{array}{l}\text { Quian et } \\
\text { al., (2020) }\end{array}$ & Pre-print & $\begin{array}{l}\text { COVID- } \\
19\end{array}$ & China & Observational & 1245 & $\begin{array}{l}\text { Community } \\
\text { and office }\end{array}$ & Suspected \\
\hline $\begin{array}{l}\text { Shen et al., } \\
(2020)\end{array}$ & $\begin{array}{l}\text { Peer review } \\
\text { journal }\end{array}$ & $\begin{array}{l}\text { COVID- } \\
19\end{array}$ & China & Observational & 67 & Temple & Observational \\
\hline $\begin{array}{l}\text { Park et al., } \\
(2020)\end{array}$ & $\begin{array}{l}\text { Peer review } \\
\text { journal }\end{array}$ & $\begin{array}{l}\text { COVID- } \\
19\end{array}$ & $\begin{array}{l}\text { South } \\
\text { Korea }\end{array}$ & Observational & 216 & Office & Suspected \\
\hline
\end{tabular}

Statistics regarding air-conditioning systems and the transmission of COVID-19 are clearly limited. The epidemics evaluation of 318 affecting, in diverse environments, 1245 contaminated people in 120 metropolises in China from 29 December to 11 February 2020, triggered Qian et al. (2020) to declare that aerosol long-range broadcast had happened in congested rooms with inadequate air-circulation. Infectious detection fragments in the atmosphere and on unreachable surfaces indicated that the disease may possibly be spread through airborne paths, and not merely contact from droplet. In the Diamond Princess cruise ship, three investigations were dedicated to the epidemic that happened, which involved 355 individuals in Japan. Subsequently, the major way for broadcast was from person to person, although other channels, as well as aerosol broadcast through drainage systems or central air 
supply, may possibly not be eliminated (Zhang et al. 2020). The research studies by Xu et al. (2020) and Mizumoto and Chowell (2020) on similar occurrence, preceded to the contrasting end. Most of the incidents started through passenger-to-passenger spread via fomites and near contact. Following the implementation of quarantine procedures, new-found incidents between commuters were reduced to those who remained in similar indoor environment with an affected passenger. Hence, ship's air-conditioning would not have played a part, i.e., the airborne lengthy-range path was not pertinent in the epidemic. From January 26 to February 10, 2020, an additional epidemic happened in a Chinese eatery and ten individuals from three relatives were, in turn, afflicted with COVID-19. The building eatery has an air-conditioning without windows, located at the fifth floor, and every single floor had its private air-conditioning system. For Lu et al. (2020) suggest that the droplet broadcast was probable triggered through the air circulation arising from the air-conditioning. The important justification for the epidemic was the direction of the airflow. Examining similar occurrence with simulations from computer, Li et al. (2020) suggest that the distribution of infection was, in turn, steady with a dispersed form characteristic of breath-out virus-laden aerosols.

\section{Discussion}

Research study explaining two additional epidemics from China in January 2020 ascribe air-conditioning systems utilizing a mode of re-transmission as a possible help to virus circulation (Shen et al. 2020). The initial epidemic was linked with a 150-minute incident at a sanctuary. Until the evening after the event, the key incident who had earlier stayed at Wuhan, was pre-symptomatic. The rate of attack in the epidemic were top between those who shared a 100-minute journey with the key incident (23 out of 67 commuters: 34\%). Commuters staying nearer to the key incident did not have an analytically greater COVID-19 risks than those staying far away. Though, every one of the commuters staying near the window stayed healthy, with the exclusion of the commuter staying behind the key incident. This confirms the theory that the flow of air near the transport aided the virus transmission. Along with 172 additional individuals who joined the same 150-minute sanctuary occasion, there were seven SARS-CoV-2 instances, each one of whom explained having had direct interaction with the key incident. From 12-14 January in Hangzhou city, Zhejiang province, the subsequent epidemic was, in turn, linked with a workshop training. Also, thirty attendees from diverse municipalities were present, who reserved resorts independently and did not dine at the same time at the service workshop. The workshop occurred in two indoor environments of 49 square meters and 75 square meters, which had group sessions of four 4-hour. A programmed regulator on the air-conditioning systems transmitted the air in every single apartment for ten minutes, using 'an indoor environment re-circulating mode' every single four hours period. For the duration of the workshop, no trainees were identified to have any symptoms. Likewise, fifteen of them were identified with COVID-19, at some point in 16-22 January 2020.

Subsequently, high efficiency particulate air filters have, in turn, shown great execution with COVID-19 size particles (roughly 70-120 nm) and are applied in healthcare and airplane environments. High efficiency particulate air filters' role in structures separate from healthcare environments in averting contagious disease transmission is unclear. The 
SARS-CoV-1 infection risk modelling study - virus triggering SARS, bestowed via three air-circulation system types in comparatively significant business aircrafts, discovered that combining air-circulation systems had the top danger and traditional transposition procedures had the smallest possible danger. Nevertheless, research study by You et al. (2019) have earlier recommend personalized air-circulation systems for cabins of commercial airline, as they were superlative in preserving thermal comfort, whereas likewise decreasing the risk of infection.

\section{Conclusion}

In conclusion, the main threat is that open window, fans, and air-conditioning systems can produce sufficient powerful air flows to transport virus-containing droplets all over the indoor environment. This occurred, according to a research by experts from the Chinese Center for Disease Control and Prevention in Guangzhou, China, where an individual with COVID-19 contaminated five more individuals staying at nearby tables from 3 to 6 feet apart. After investigating the infected diners' film recordings and simulating the virus transmission, experts decided that air was blowing virus-containing aerosols from the contaminated individual to those nearby and the minor occurrence was produced through strong air flows from the air-conditioning system above the diners. The eatery likewise had no windows - and hence no air-circulation taking in clean air and weakening particles of virus in the air.

Therefore, the state-of-the-art evidence clearly shows that:

- COVID-19 transmission generally happens in indoor environments.

- No evidence of human disease with COVID-19 triggered via transmissible aerosols dispersed by the air-circulation system channels of air-conditionings. The threat is therefore assessed as extremely low.

- Appropriately kept air-conditioning system filters significant droplets having COVID-19. It is plausible for the aerosols of SARS-CoV-2 (droplet nuclei and small droplets) to transmit via air-conditioning systems within the indoor environment if air is retransmitted.

- Flow of air produced through air-conditioning systems can expedite the transmission of droplets emitted via contaminated individuals in extended spaces within indoor environments.

- Air-conditionings can have a harmonizing part in diminishing virus spread in indoor environments through expanding air change rate, enhancing the use of outdoor air and reducing indoor air recirculation.

\section{References}

Azzoni, T., \& Dampf, A. (2020). Game Zero: Spread of virus linked to Champions League match: Associated Press, 2020. [Online] Available:

https://apnews.com/ae59cfc0641fc63afd09182bb832ebe2

Deutsche, W. (2020). 1.8 million people in Germany could be infected with coronavirus, 
researchers find. [Online] Available:

https://www.dw.com/en/18-million-people-in-germany-could-be-infected-with-coronavirus-re searchers-find/a-53330608

Dietz, L., Horve, P. F., Coil, D. A., Fretz, M., Eisen, J. A., \& Van Den Wymelenberg, K., (2020). 2019 Novel Coronavirus (COVID-19) Pandemic: Built Environment Considerations to Reduce Transmission. mSystems, 5(2), e00245-20.

https://doi.org/10.1128/mSystems.00245-20

Gilkeson, C. A., \& Noakes, C. (2013). Application of CFD simulation to predicting upper-room UVGI effectiveness. Photochem. Photobiol, 89, 799-810.

https://doi.org/10.1111/php.12013

Hamner, L., Dubbel, P., Capron, I., Ross, A., Jordan, A., \& Lee, J. (2020). High SARS-CoV-2 Attack Rate Following Exposure at a Choir Practice - Skagit County, Washington, March 2020. Morb Mortal Wkly Rep Surveill Summ, 2020(69), 606-10.

https://doi.org/10.15585/mmwr.mm6919e6

ISO. (2017). Energy performance of buildings. Indoor environmental quality. Indoor environmental input parameters for the design and assessment of energy performance of buildings.

Leclerc, Q. J., Fuller, N. M., Knight, L. E., Funk, S., \& Knight, G. M. (2020). What settings have been linked to SARS-CoV-2 transmission clusters? Wellcome Open Research, 5(83). https://doi.org/10.12688/wellcomeopenres.15889.2

Li, Y., Qian, H., Hang, J., Chen, X., Hong, L., \& Liang, P. (2020). Evidence for probable aerosol transmission of SARS-CoV-2 in a poorly ventilated restaurant. medRxiv. https://doi.org/10.1101/2020.04.16.20067728

Lu, J., Gu, J., Li, K., Xu, C., Su, W., \& Lai, Z. (2020). COVID-19 Outbreak Associated with Air Conditioning in Restaurant, Guangzhou, China, 2020. Emerg Infect Dis, 26(7). https://doi.org/10.3201/eid2607.200764

Mizumoto, K., \& Chowell, G. (2020). Transmission potential of the novel coronavirus (COVID-19) onboard the diamond. Princess Cruises Ship, 2020. Infect. Dis. Model, 5, 264-270. https://doi.org/10.1016/j.idm.2020.02.003

Oye, T. T., Goh, K., Gupta, N., \& Oye, T. K. (2020d). Development of Optimized Smart Indoor Control for Renewable Air-Conditioning. 2020 9th International Conference on Renewable Energy Research and Application (ICRERA), IEEE Xplore, Glasgow, United Kingdom. pp. 175-179. https://doi.org/10.1109/ICRERA49962.2020.9242846

Oye, T. T., Gupta, N., Goh, K., \& Oye, T. K. (2020b). Theoretical Assessment of Sustainability Principles for Renewable Smart Air-Conditioning. Journal of Environmental Management and Sustainable Development, 9(3), 18-46.

https://doi.org/10.5296/emsd.v9i3.16953

Park, S. Y., Kim, Y. M., Yi, S., Lee, S., Na, B. J., \& Kim, C. B. (2020). Coronavirus Disease 


\section{Macrothink \\ Environmental Management and Sustainable Development \\ ISSN 2164-7682 \\ 2021, Vol. 10, No. 3}

Outbreak in Call Center, South Korea. Emerg Infect Dis, 26(8).

https://doi.org/10.3201/eid2608.201274

Phiri, M. (2014). Health Building Note 00-01 General design Guidance for Healthcare Buildings. UK Government.

Qian, H., Miao, T., Liu, L., Zheng, X., Luo, D., \& Li, Y. (2020). Indoor transmission of SARS-CoV-2. medRxiv. https://doi.org/10.1101/2020.04.04.20053058

Shen, Y., Li, C., Dong, H., Wang, Z., Martinez, L., \& Sun, Z. (2020). Airborne transmission of COVID-19: epidemiologic evidence from two outbreak investigations.

https://doi.org/10.2139/ssrn.3567505

Thatiparti, D. S., Ghia, U., \& Mead, K. R. (2016). Assessing effectiveness of ceiling-ventilated mock airborne infection isolation room in preventing hospital acquired influenza transmission to health care workers. ASHRAE Trans, 122, 35.

Thatiparti, D. S., Ghia, U., \& Mead, K. R. (2017). Computational fluid dynamics study on the influence of an alternate ventilation configuration on the possible flow path of infectious cough aerosols in a mock airborne infection isolation room. Sci. Technol. Built Environ, 23, 355-366. https://doi.org/10.1080/23744731.2016.1222212

WHO. (2009). Natural ventilation for infection control in health-care settings. In Y. Chartier, C. Pessoa-Silva, Y. Li, \& W. H. Seto (Eds.), World Health Organization. [Online] Available: www.who.int/water_sanitation_health/publications/natural_ventilation/en/

Xu, P., Qian, H., Miao, T., Yen, H. L., Tan, H., Kang, M., Cowling, B. J., \& Li, Y. (2020). Transmission routes of Covid-19 virus in the Diamond Princess Cruise ship. medRxiv. https://doi.org/10.1101/2020.04.09.20059113

You, R., Lin, C. H., Wei, D., \& Chen, Q. (2019). Evaluating the commercial airliner cabin environment with different air distribution systems. Indoor air, 29(5), 840-53.

https://doi.org/10.1111/ina.12578

Zhang, S., Diao, M. Y., Yu, W., Pei, L., Lin, Z., \& Chen, D. (2020). Estimation of the reproductive number of novel coronavirus (COVID-19) and the probable outbreak size on the Diamond Princess cruise ship: A data-driven analysis. Int. J. Infect. Dis, 93, 201-204.

https://doi.org/10.1016/j.ijid.2020.02.033

\section{Copyright Disclaimer}

Copyright for this article is retained by the author(s), with first publication rights granted to the journal.

This is an open-access article distributed under the terms and conditions of the Creative Commons Attribution license (http://creativecommons.org/licenses/by/4.0/). 